\title{
Bioconversion of crude glycerol from waste cooking oils into hydrogen by sub-tropical mixed and pure cultures
}

\author{
Caroline Varella Rodrigues ${ }^{a, b, *}$, Maurílio Gustavo Nespeca ${ }^{c}$, \\ Isabel Kimiko Sakamoto ${ }^{d}$, José Eduardo de Oliveira ${ }^{c}$, \\ Maria Bernadete Amâncio Varesche ${ }^{d}$, Sandra Imaculada Maintinguer ${ }^{b, e}$ \\ a Institute of Chemistry-IQ UNESP, Prof. Francisco Degni 55, Zip Code, 14800-060, Araraquara, SP, Brazil \\ b Bioenergy Research Institute-IPBEN, UNESP, 13550-230, Rio Claro, SP, Brazil \\ ${ }^{\mathrm{c}}$ Center for Monitoring and Research of the Quality of Fuels, Biofuels, Crude Oil, and Derivatives, Institute of \\ Chemistry-CEMPEQC, UNESP, Prof. Francisco Degni 55, Zip Code, 14800-060, Araraquara, SP, Brazil \\ ${ }^{\mathrm{d}}$ Department of Hydraulics and Sanitation, School of Engineering of São Carlos, University of São Paulo, Av. João \\ Dagnone, 1100, Jd. Santa Angelina, Zip Code, 13563-120, São Carlos, SP, Brazil \\ e University of Araraquara, R. Voluntários da Pátria, 1309, Zip Code, 14801-320, Araraquara, SP, Brazil
}

\section{A R T I C L E I N F O}

Article history:

Received 14 November 2017

Received in revised form

22 February 2018

Accepted 26 February 2018

Available online 23 March 2018

Keywords:

Biodiesel

Biohydrogen

Clostridium sp.

Enterobacter sp.

Illumina MiSeq sequencing

1,3-Propanediol

\begin{abstract}
A B S T R A C T
This study compared the biohydrogen generation by sub-tropical mixed and pure cultures from the crude glycerol from the biodiesel production using waste cooking oils (WCO). The crude glycerol was pretreated by $\mathrm{pH}$ adjustment. The mixed culture was obtained from a subtropical granular sludge of the UASB (Upflow Anaerobic Sludge Blanket) reactor used in the treatment of vinasse from sugarcane of ethanol and sugar industry. It was heat treated in order to inactivate hydrogen-consuming bacteria, which was identified by Illumina MiSeq Sequencing with a relative abundance of 97.96\% Firmicutes Philum, 91.81\% Clostridia Class and $91.81 \%$ Clostridiales Order. The pure culture was isolated from a sub-tropical granular sludge from UASB reactor of treating brewery wastewater and identified as Enterobacter sp. (KP893397). Two assays were carried in anaerobic batch reactors in order to verify the hydrogen production from crude glycerol bioconversion with: (I) mixed culture and (II) pure culture. The experiments were conducted at $37^{\circ} \mathrm{C}$, initial pH of 5.5 for assay I and 7.0 for assay II, with $20 \mathrm{~g} \mathrm{COD} \mathrm{L}^{-1}$ of crude glycerol. The crude glycerol consumption was $56.2 \%$ and $88.0 \%$ for the assay I and II, respectively. The hydrogen yields were $0.80 \mathrm{moL}$ $\mathrm{H}_{2} \mathrm{~mol}^{-1}$ glycerol for the assay I and $0.13 \mathrm{moL} \mathrm{H}_{2} \mathrm{~mol}^{-1}$ glycerol for the assay II. Enterobacter sp. preferred the reductive metabolic route, generating $1460.0 \mathrm{mg} \mathrm{L}^{-1}$ of 1,3-propanediol, and it showed to be more sensitive in the presence of methanol from crude glycerol than mixed culture that preferred the oxidative metabolic route with biohydrogen generation. The mixed culture was more able to generate $\mathrm{H}_{2}$ than pure culture from the crude glycerol coming from the biodiesel production using WCO.
\end{abstract}

๑) 2018 Hydrogen Energy Publications LLC. Published by Elsevier Ltd. All rights reserved.

\footnotetext{
* Corresponding author. Institute of Chemistry-IQ UNESP, Prof. Francisco Degni 55, Zip Code, 14800-060, Araraquara, SP, Brazil.

E-mail addresses: carolvr61@hotmail.com (C.V. Rodrigues), mainting2008@gmail.com (S.I. Maintinguer). 


\section{Introduction}

Biodiesel is one of the biofuel sources, which can be made from waste cooking oil (WCO) in a transesterification process [1]. According to Mansir et al. (2018), about 15 million tons of waste cooking oil is annually been disposed inadequately in water or land across the globe [2]. The Basic Sanitation Company of the State of São Paulo (SABESP), in Brazil, in 2010, released a report that only $2.5-3.5 \%$ of edible vegetable oil discarded in Brazil is recycled [3]. It is estimated that each WCO liter generates $980 \mathrm{~mL}$ of biodiesel [4]. Despite the WCO potential for biodiesel production in Brazil, only $0.80 \%$ of this biofuel was produced from WCO in January 2017 [5].

The use of WCO represents a double benefit that makes it a very good environment-friendly feedstock. First, it is cheaper than virgin vegetable oils and second, it can be re-used and transformed, preventing their discarding into the sewer that it causes water pollution and the cost increase of water treatment [6].

According to Rodrigues et al. (2016) [7], the WCO applied as a feedstock for the biodiesel production reduces the costs for this process of $60-70 \%$. In São Paulo, Brazil, on March/April 2017 , the WCO had price of $\mathrm{R} \$ 1.00$ per liter [8], while raw virgin of soybean oil price was $\mathrm{R} \$ 2.57$ per liter [9], a price of almost 2.6 more than WCO.

The biodiesel industry has shown enormous growth in past few years [10]. This production in Brazil is encouraged by law, as established by the National Program for the Production and Use of Biodiesel, which increased with the percentage increase of biodiesel mixed with diesel oil over the years, according to Brazilian government policy [1].

Biodiesel industry generates large amounts of crude glycerol as co-product, being $10 \mathrm{~kg}$ for each $100 \mathrm{~kg}$ of biodiesel produced [11]. With global production of biodiesel crossing 20 billion liters, very large quantities of glycerol will be generated [10]. This excess of crude glycerol cannot be absorb by the traditional industries for conventional applications, such as in cosmetics, food and pharmaceutical industry, because this waste contains various impurities, such as methanol, water, soaps, free fatty acids or fatty acids methyl esters, coming from the transesterification process, and its purification is expensive, especially for small and average companies [12]. For this reason, the large quantities of crude glycerol produced each year have impacted the glycerol market, resulting in low prices of crude glycerol (1.54 US \$/Kg before 2000 and 0.66 US \$/Kg after 2007). Crude glycerol has been a financial and environmental liability of the biodiesel industry $[7,13]$.

Increasing abundance, with the biodiesel production increasing, and decreasing market price, makes crude glycerol a potential substrate for fermentation to produce hydrogen [14]. The composition in this organic matter and the basic elements that make it up is one of the reasons of why crude glycerol has been used as a promising carbon source for microbiological processes [15]. This bioconversion provides biodegradable compounds, being a benefit for the environment, promoting the improvement of the economic viability of the biodiesel industry $[15,16]$.
The glycerol metabolism can be given by two routes, oxidative and reductive, being known for some species such as Klebsiella sp., Citrobacter sp., Clostridium sp. and Enterobacter $\mathrm{sp}[17,18]$. In the oxidative pathway, the crude glycerol can be converted to $\mathrm{H}_{2}$ in addition to lactate, acetate, butyrate, butanol, ethanol, 2,3-butanediol and propionate, for example. In the reductive pathway, the crude glycerol is finally converted to 1,3-propanediol (1,3-PD). So, the 1,3-PD and $\mathrm{H}_{2}$ are the two major products which can be obtained by crude glycerol bioconversion [19].

Hydrogen production is attractive for its high-energy content, $141.9 \mathrm{MJ} \mathrm{kg}^{-1}$, and it is considered as a promising alternative to fossil fuels, producing water rather than greenhouse gases during its combustion. The 1,3-PD has important applications and it can be used as a solvent, monomers for cyclic compounds, and monomers for condensation to produce plastics $[20,21]$.

Most studies on fermentation process have focused on the use of pure cultures for the bioconversion of crude glycerol due to the fact that they generally exhibit higher yields than those with mixed cultures [20]. These species can be Klebsiella sp. [22,23], Enterobacter sp. [14,15] and Clostridium sp. [24], for example.

However, the use of pure cultures involves expensive equipment and complicated protocols. In contrast, methods with mixed cultures do not require these procedures, adopted by pure cultures, and they are easy to implement, incurring lower costs and fewer contamination problems [20].

The strains belonging to Enterobacteriaceae family and Clostridiaceae family are also potential microorganisms for bioconversion of crude glycerol into variety of products. Clostridium species have much higher potential for biohydrogen production than the Enterobacter species. The metabolism of Enterobacter species can produce maximum of 1 mol hydrogen per mole of glycerol, while metabolism of Clostridium species can produce 3 mols hydrogen per mole of glycerol [10].

The main goal of this study consisted in a comparison, has never been employed, involving the biohydrogen production between mixed and pure culture with crude glycerol from the biodiesel production in a transesterification process of used cooking oils.

\section{Materials and methods}

\section{Crude glycerol (CG)}

CG was obtained from a Pilot Plant of Biodiesel Production from the Biotechnology Institute of Engineering Renewable Energy of UNIARA - University of Araraquara (Araraquara Brazil) through transesterification of waste cooking oils with sodium hydroxide $(\mathrm{NaOH})$ as catalyst and methanol as short chain alcohol for this reaction. The composition of CG (by w/ w) is shown in Table 1 :

The CG was pretreated by the $\mathrm{pH}$ adjustment to 3.0 with hydrochloric acid $\left(1 \mathrm{~mol} \mathrm{~L}^{-1}\right)$ to convert the soluble soap into insoluble free fatty acids in order to remove it from the crude glycerol phase $[25,26]$. 
Table 1 - Characterization of the CG from biodiesel production through transesterification of WCO [8].

\begin{tabular}{ll} 
Parameter & Value \\
\hline pH & 10.00 \\
Chemical Oxygen Demand (COD) $\left(\mathrm{g} \mathrm{L}^{-1}\right)$ & 1961.33 \\
Glycerol (m/m) (\%) & 10.41 \\
Moisture and Volatile Matter (\%) & 22.75 \\
Water $(\%)$ & 5.84 \\
Soap $(\mathrm{m} / \mathrm{m})(\%)$ & 23.38 \\
Methanol (m/m) (\%) & 15.84 \\
Ash $(\mathrm{m} / \mathrm{m})(\%)$ & 3.04 \\
Matter Organic Non Glycerol (MONG) (v/v) (\%) & 34.57 \\
\hline
\end{tabular}

\section{Mixed culture}

Growth conditions and hydrogen-producing bacteria obtainment

The hydrogen-producing bacteria from the mixed culture was obtained from a granular sludge of the thermophilic Upflow Anaerobic Sludge Blanket (UASB) reactor $\left(55^{\circ} \mathrm{C}\right)$ used in the treatment of vinasse from sugarcane of ethanol and sugar industry (São Martinho, Pradópolis - Brazil).

The growth conditions were made in anaerobic batch reactors (100 mL-total volume) with PYG culture media modified $(50 \mathrm{~mL})$ composed of glycerin $\left(10.0 \mathrm{~g} \mathrm{~L}^{-1}\right)$, peptone $\left(5.0 \mathrm{~g} \mathrm{~L}^{-1}\right)$, yeast extract $\left(5.0 \mathrm{~g} \mathrm{~L}^{-1}\right)$ and meat extract $\left(5.0 \mathrm{~g} \mathrm{~L}^{-1}\right)$, in distilled water at $\mathrm{pH}$ of 7.0 , by the flush of $\mathrm{N}_{2}(100 \%)$. After the preparation, the culture media was sterilized $\left(120{ }^{\circ} \mathrm{C}, 20 \mathrm{~min}\right)$. The cellular suspension $(20 \% \mathrm{v} / \mathrm{v})$ from mixed culture was transferred, separately, to culture media in anaerobic batch reactors and they are maintained at $37^{\circ} \mathrm{C}$ during 7 days without agitation.

The mixed culture was submitted to heat treatment (100 ${ }^{\circ} \mathrm{C}$, for $15 \mathrm{~min}$ ) in order to inactivate the hydrogen consumers and harvest the spore-forming anaerobic bacteria, such as Clostridium sp [27]. Afterwards, serial dilutions $\left(10^{-1}\right.$ until $10^{-6}$ ) were performed on new sterile PYG media modified, $\mathrm{pH}$ of 5.5 and headspace filled with $\mathrm{N}_{2}(100 \%)$. The mixed culture, of $10^{-6}$ dilution, was used for the inoculation in the anaerobic batch reactors for the assembled assays.

\section{Microbiological analysis}

The identification of the mixed culture was carried out in Miseq - Illumina. The Total genomic DNA was obtained after the cell lysis with glass beads and the extraction with phenolchloroform as described by Griffiths et al. (2000) [28]. The step of obtaining the raw data was done by CASAVA software 1.8.2, provided by Illumina, which made the base call of the raw data and transformed them into reads in the fastq format accompanied by scores of phred quality. Reads were viewed using the FastQC program (www.bioinformatics.bbsrc.ac.uk/ projects/). The filtering of low quality reads, adapter sequences and vectors were performed by the Seqyclean program (https://bitbucket.org/izhbannikov/seqyclean), using cutoff bases with a quality lower to $24 \mathrm{QScore}$. The contaminant database used was Univec (http://www.ncbi.nlm.nih. gov/VecScreen/UniVec.html). After filtration, reads with size less than $65 \mathrm{pb}$ were removed.
The RDP database [29] of Bacteria was used for metagenomic analysis. The pipeline used was the QIIME v 1.9 package [30] in 3 steps: 1) Concatenation of reads paired-end; 2) Filtering, searching and identifying OTUs (Operational Taxonomic Units). At this stage the program also performed a reassemble of reads that had no hit with the database and sought hit against all available bases; 3) Rarefaction analysis, alpha and beta diversity.

The QIIME scripts used for four or more samples were: pick_open_reference_otus.py; merge_otu_tables.py; biom convert; biom summarize-table; core_diversity_analyses.py. For up to three samples: pick_open_reference_otus.py; biom convert; biom summarize-table; alpha_diversity.py; beta_diversity.py; alpha_rarefaction.py.

The sequences were submitted to the National Center for Biotechnology Information - NCBI (http://www.ncbi.nlm.nih. gov) by the Sequence Read Archive (SRA) number SRP075454, under accession numbers: SRX1786831 (Fermentative anaerobic bacteria consortia to generate hydrogen). The project accession number is PRJNA322194.

\section{Pure culture}

The pure culture was obtained from a granular sludge from UASB reactor treating brewery wastewater Araraquara Brazil). It was isolated and identified as Enterobacter sp. (accession number KP893397 from NCBI database) [31].

\section{Operation of the anaerobic batch reactors with mixed and pure cultures}

The anaerobic batch reactors were prepared in duplicate in Duran ${ }^{\circledR}$ flasks with a total volume of $1 \mathrm{~L}$ and working volume of $650 \mathrm{~mL}$ of PYG media modified $\left(5.0 \mathrm{~g} \mathrm{~L}^{-1}\right.$ of peptone, $5.0 \mathrm{~g} \mathrm{~L}^{-1}$ of yeast extract and $5.0 \mathrm{~g} \mathrm{~L}^{-1}$ of meat extract) with $20 \mathrm{~g} \mathrm{COD} \mathrm{L}^{-1}$ of crude glycerol, $\mathrm{pH}$ of 5.5 (for mixed culture) and $\mathrm{pH}$ of 7.0 (for pure culture), headspace ( $350 \mathrm{~mL}$ ) filled with $\mathrm{N}_{2}(100 \%)$ for $15 \mathrm{~min}$, at $37^{\circ} \mathrm{C}$. For each assay, $20 \%$ (v/v) of the mixed culture (assay I) and pure culture (assay II) were added, separately, to duplicates of anaerobic batch reactors (1 L) containing $650 \mathrm{~mL}$ of PYG media modified, as described previously. They were then capped with butyl rubber stoppers. In these assays, it was able to quantify the hydrogen production, CG consumption, volatile fatty acids and alcohols generated and 1,3-PD generation.

\section{Chromatographic and chemical analysis}

The biogas (hydrogen, methane and carbon dioxide) was determined through chromatographic analysis simultaneously in a single run in a TOGA (Transformer Oil Gas Analyser) system, coupled with a Trace GC Ultra - Thermo Gas Chromatograph, equipped with split/splitless injectors and two detectors: thermal conductivity detector (TCD) and flame ionization detector (FID) with methanizer. The fraction containing hydrogen, nitrogen and methane was analyzed by RtMSieve $5 \mathrm{~A}^{\circ} 30 \mathrm{~m} \times 0.53 \mathrm{~mm}$ i.d. column. Hydrogen and nitrogen were detected by TCD and methane was detected by FID, after passing through the methanizer. The carbon dioxide 
was eluted from the porous polymer Carboxen 1006 plot $30 \mathrm{~m} \times 0.53 \mathrm{~mm}$ i.d column and detected by the FID, after passing through the methanizer. Argon was used as a carrier gas (1.5 $\mathrm{mL} \mathrm{min}^{-1}$ in splitless mode). The temperature of TCD detector and injector were adjusted to $150^{\circ} \mathrm{C}$. The oven programing was at $50{ }^{\circ} \mathrm{C}(4.5 \mathrm{~min})$, heating rate $40{ }^{\circ} \mathrm{C} \mathrm{min}^{-1}$ to $180{ }^{\circ} \mathrm{C}(1.5 \mathrm{~min})$, and then, cooling rate $50{ }^{\circ} \mathrm{C} \mathrm{min}^{-1}$ to $50{ }^{\circ} \mathrm{C}$ (3.15 $\mathrm{min}$ ). The production of $\mathrm{H}_{2}$ was calculated considering the atmospheric pressure, expressed as mmol $\mathrm{H}_{2} \mathrm{~L}^{-1}$ [32].

The methanol concentrations, coming from to the crude glycerol, were measured by gas chromatography, using a Shimadzu gas chromatography (GC model 2010), with Split/ Splitless injector and a flame ionization detector (FID) of high frequency, a COMBI-PAL headspace auto-sampler system (AOC 5000), a programmable temperature vaporizing injector (PTV) and FID detector at the temperature of $300^{\circ} \mathrm{C}$. The oven temperature was programmed initially at $50{ }^{\circ} \mathrm{C}$ for $1 \mathrm{~min}$, followed by a heating ramp of $60^{\circ} \mathrm{C} \mathrm{min}^{-1}$ up to a final temperature of $250{ }^{\circ} \mathrm{C}$, maintained for $2 \mathrm{~min}$. The analytical column used was DB-1 MS $(20 \mathrm{~m} \times 0.10 \mathrm{~mm} \times 0.4 \mu \mathrm{m})$. As for the carrier gas used, it was hydrogen at a constant linear velocity of $63 \mathrm{~cm} \mathrm{~s}^{-1}$ (1 $\left.\mathrm{mL} \mathrm{min}^{-1}\right)$ and flow rate splitting (split) 1:100 [33].

The 1,3-PD concentration was determined in a High Performance liquid Chromatography (HPLC) of Shimadzu, Prominence series, with Refractive Index (RI) detector. The column used was Rezex ROA $(300 \times 7.8 \mathrm{~mm})$ from Phenomenex, eluted with $\mathrm{H}_{2} \mathrm{SO}_{4} 0.005 \mathrm{~N}$ as mobile phase, flow rate of $0.6 \mathrm{~mL} \mathrm{~min} \mathrm{~m}^{-1}$, injection volume of $5 \mu \mathrm{L}$ and temperature of $65^{\circ} \mathrm{C}$.

The organic compounds concentrations, such as volatile fatty acids and alcohols were measured by gas chromatography using a GC $2010\left(\right.$ Shimatzu $\left.^{\circledR}\right)$, configured for liquid and headspace sampling, a programmable temperature of PTV and FID detector at $250{ }^{\circ} \mathrm{C}$. The oven temperature was programmed initially at $45^{\circ} \mathrm{C}$ for $1 \mathrm{~min}$, followed by a heating ramp of $50{ }^{\circ} \mathrm{C} \mathrm{min}^{-1}$ up to a final temperature of $250{ }^{\circ} \mathrm{C}$, maintained for $3 \mathrm{~min}$. The analytical column used was RTX-1 $(30 \mathrm{~m} \times 0.32 \mathrm{~mm} \times 3.0 \mu \mathrm{m})$. Helium was used as the carrier gas $51.6 \mathrm{~cm} \mathrm{~s}^{-1}\left(1 \mathrm{~mL} \mathrm{~min}^{-1}\right)$ [34].

The crude glycerol consumption was analyzed by spectrophotometric method [35]. The $\mathrm{pH}$ value was performed. The cellular growth was based on the optical density at $600 \mathrm{~nm}\left(\mathrm{OD}_{600}\right)$ [36].

\section{Experimental data fitting}

The experimental data obtained during the assays I and II were adjusted to average values of duplicates in batch reactors using the software Statistic ${ }^{\circledR}$ (version 8.0), according to Equation (1). The maximum rate of hydrogen production was obtained through nonlinear sigmoidal adjustment of the modified Gompertz function [37].

$\mathrm{H}=\mathrm{P} x \exp \left\{-\exp \left[\frac{\text { Rm.e }}{\mathrm{P}}(\lambda-\mathrm{t})+1\right]\right\}$

$\mathrm{H}$ presents the cumulative hydrogen (mmol), $\mathrm{P}$ is the hydrogen production potential $\left(\mathrm{mmol} \mathrm{L}^{-1}\right), \mathrm{Rm}$ is the maximum rate of hydrogen production $\left(\mathrm{mmol} \mathrm{L}^{-1} \mathrm{~h}\right), \lambda$ is the lag phase time (h), e is 2,718281828 and $t$ is the incubation time (h).

\section{Results and discussion}

\section{Mixed culture: community composition of and diversity}

Illumina MiSeq Sequencing produced a total of 179255 sequences with similarity index of $97 \%$. These sequences were assigned to $200 \mathrm{OTU}_{\mathrm{S}}$. Shannon index of 1.033 indicated the community diversity while Chao estimators represent the community richness of 772 [38]. Ratti et al. (2015) [39] studied the composition and diversity of the bacterial community, obtained from a granular sludge from a thermophilic UASB reactor used in the treatment of stillage from sugarcane (the same inoculum source as in the present study), in reactors, during the $\mathrm{H}_{2}$-production fed with glucose incubated at $55^{\circ} \mathrm{C}$ using pyrosequencing. The experiments were conducted using 0.5 and $2.0 \mathrm{~g} \mathrm{~L}^{-1}$ glucose. They were obtained as the Shannon index 5.25 and 5.00, respectively. During the discussion of the Ratti's paper, these index values were high, indicating the high community diversity. So, the Shannon index in this present work was around 5 times lower than the values obtained in the work of Ratti et al., may indicate low community diversity. Unlike the work of Ratti et al., in the present study, the inoculum from the thermophilic UASB reactor was incubated at $37^{\circ} \mathrm{C}$ (mesophilic conditions) for the assembly the assays. This change from thermophilic to mesophilic conditions could have provided a previously selection of $\mathrm{H}_{2}$-producing bacteria, leading to low community diversity, as indicated by the Shannon index in the present study.

Xie et al. (2016) [38] studied the difference between microbial communities of sludge samples in hydrolysis acidification reactors used to deal with simulated dyeing wastewater containing Reactive Black 5 (RB5) and Remazol Brilliant Blue R (RBBR) by Illumina MiSeq Sequencing. The Chao estimators obtained were 146 and 121, respectively. According to Xie et al., their results were high, indicating higher microbial richness. So, in the present studied, the Chao estimator was 772, a value higher than obtained in the Xie's paper, indicating, therefore, high microbial richness.

The bacterial phylotype richness levels can also be determined using rarefaction curve (Fig. 1). It was observed that the

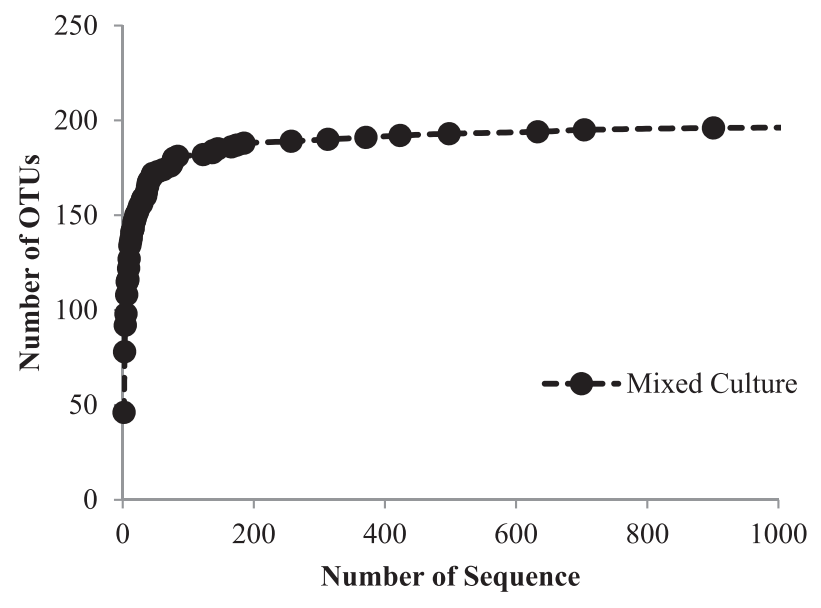

Fig. 1 - Rarefaction curve of OTUs defined by mixed culture used for crude glycerol consumption in anaerobic batch reactors. 
curve reached a plateau after 200 sequences, showing stabilization. According to Ratti et al. (2015) [39], it suggests that the number of sequences was sufficient to cover the whole bacterial diversity. In addition, according to Xie et al. (2016) [38], as the curve become relatively flat as the number of sequences increased, it is guaranteed that there is rationality and accuracy of the results.

Furthermore, the low OTU ratio was given by the pretreatment of the inoculum during seven days in the culture medium with glycerin, corresponded to a previous step of selection $\mathrm{H}_{2}$-producing bacteria. Before assembling the assays, the inoculum was submitted to a reactivation in PYG medium containing glycerin as carbon source to favor the growth of fermentative microorganisms. The granular sludge used in the present study corresponds to a predominantly methanogenic sludge. The period of seven days was enough for the entire exponential phase of fermentative microorganisms growth to be achieved [40] and, at the same time, it inhibit the activity of the methanogenic microorganisms, since they require a period of more than 15 days for its development [41], [42]. The inoculum that underwent a pretreatment process, obtained from granular methanogenic sludge and environmental samples, such as soil, water, among others, used for the biological $\mathrm{H}_{2}$-production, presents a reduction in the relative abundance of species with consequent low OTU ratio [39], [43].

According to the RDP-Classifier, the most prevalent phylum was Firmicutes (97.96\%). Member of the Proteobacteria was present at an abundance of $1.57 \%$ (Fig. 2A). According to the literature, Firmicutes phylum encompasses the main microorganisms that produce $\mathrm{H}_{2}[39,44]$. Microorganisms of the phylum Firmicutes performed the most important role in the fermentation process of the organic matter decomposition [45].

Sittijunda et al. (2017) [46] studied the influence of organic loading rate (OLR) $\left(25,37.5,50,62.5 \mathrm{~g} \mathrm{~L}^{-1} \mathrm{~d}\right)$ on hydrogen, ethanol, and 1,3-PD production from crude glycerol in a UASB reactor by anaerobic mixed cultures. Analysis of microbial community by biomolecular analyses indicated that the predominant hydrogen producers at the optimum OLR (50 g L ${ }^{-1} \mathrm{~d}$ ), were Clostridium sp., Enterobacter sp., uncultured Firmicutes bacterium, and uncultured Actinobacterium. According to Sittijunda et al. (2017), these microorganisms are recognized as effective hydrogen producers capable of utilizing a wide range of substrates such as glycerol. Thus, it was evident that the participation and importance of microorganisms belonging to this phylum in the hydrogen production during the crude glycerol consumption.

Firmicutes phylum is Gram-positive, endospore-forming, mainly belonging to the Bacilli and Clostridia classes [44]. The relative abundance for these classes was $61.40 \%$ for Bacilli and 91.81\% for Clostridia (Fig. 2B). Members of the Gammaproteobacteria were present at an abundance of $1.57 \%$.

According to Maintinguer et al. (2015) [44], microorganisms belonging to Bacilli and Clostridia classes produce $\mathrm{H}_{2}$ during the exponential growth phase in batch growth and they could be easily obtained by heat treatment of the anaerobic sludges. This procedure for selective $\mathrm{H}_{2}$ bacteria was performed for a subtropical sludge in the present study, allowing its permanence in the mixed culture, being found a high relative abundance for both.
(A)

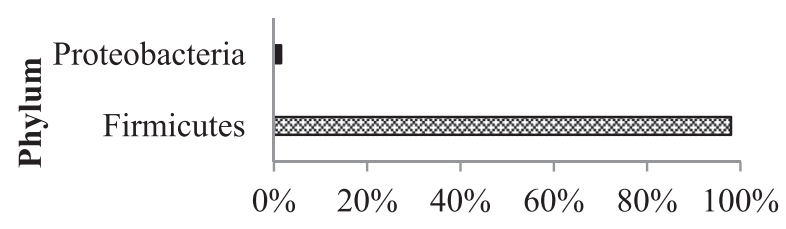

(B)

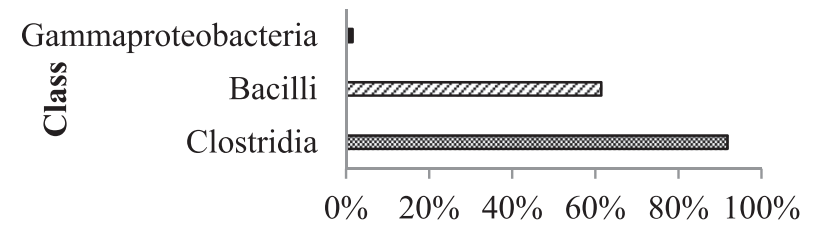

(C)

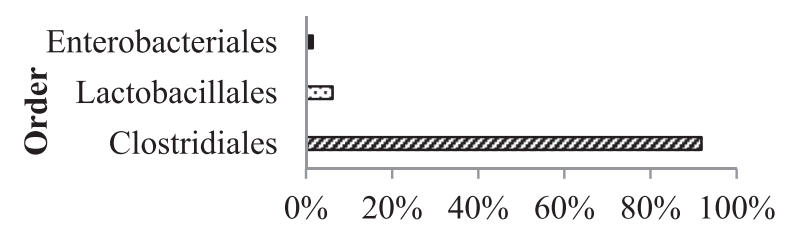

(D)

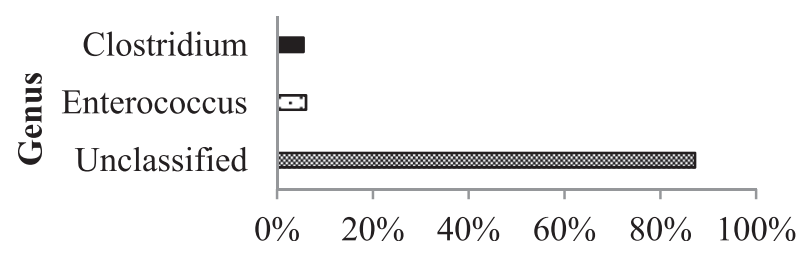

Fig. 2 - Relative abundance of (A) phylum, (B) class, (C) order and (D) genus in mixed culture used for crude glycerol consumption in anaerobic batch reactors.

The microorganisms from the Clostridiales order represented the greatest relative abundance (91.81\%) (Fig. 2C) and this order contains the Clostridiaceae family as well as the genus Clostridium [47]. This genus represents potential microorganisms for bioconversion of crude glycerol into variety of products [10].

In the present study, it was observed uncultivated bacteria (Fig. 2D) from Clostridia class. The knowledge about microorganisms present in the environment is predominantly based on pure laboratory cultures and only $1 \%$ of bacteria from the different ecosystems have been identified [48]. Maintinguer et al. (2011) [49] operated anaerobic batch reactors with inoculum obtained from the slaughterhouse wastewater treatment UASB reactor to producing $\mathrm{H}_{2}$ fed with xylose $0.5-4 \mathrm{~g} \mathrm{~L}^{-1}$ and they observed through molecular biological analysis uncultivated bacteria. Ratti et al. (2015) [39] investigated the bacterial diversity in thermophilic $\mathrm{H}_{2}$-producing reactors with glucose identifying uncultivated bacteria. In these papers, discussed above, the authors observed that uncultivated bacteria from Clostridia class. Therefore, it was expected to obtain uncultivated bacteria and it is important to say that they were from Clostridia class (Fig. 2B) that they are recognized in the literature as $\mathrm{H}_{2}$-producing. 


\section{Operation of anaerobic batch reactors}

The anaerobic batch reactors were assembled with mixed culture, with the predominance of Clostridium species, as it can be seen in the section above (assay I) and with Enterobacter sp. (assay II), in separated reactors. The results obtained are indicated in Table 2.

\section{CG consumption}

The CG consumptions were $56.2 \%$ and $88.0 \%$ for assay I and II, respectively (Table 2). By this way, a high percentage of crude glycerol was consumed throughout the experiments with pure culture Enterobacter sp. However, its consumption was not complete and not so fast, as reported in the work of Ito et al. (2005) [50], in which the pure culture Enterobacter aerogenes was tested. For the assembly of the batch reactors of the present study, the initial concentration of crude glycerol was higher, $3.66 \mathrm{~g} \mathrm{~L}^{-1}$, than that used in the work of Ito et al. (2005), $1.7 \mathrm{~g} \mathrm{~L}^{-1}$. Thus, the greater the input charge of the crude glycerol is, the more contaminants exist were carried, leaving the medium saturated with impurities, such as methanol and soap, being a difficulty for the microbiological activity, thus justifying the incomplete consumption of the substrate and occurring in a longer time $(90 \mathrm{~h})$ than was reported in the literature in Ito's work $(4 \mathrm{~h})$.

Nevertheless, the crude glycerol consumption was high for the Enterobacter sp. (assay II) when it was compared to the assay I containing the mixed culture. According to Sarma et al. (2013) [51] certain concentrations of alcohol, such as methanol present in crude glycerol, may improve cell permeability and probable improvement in glycerol uptake rate. Thus, for this concentration of $1.2 \mathrm{~g} \mathrm{~L}^{-1}$ of methanol, a high consumption of the substrate was found due to the increase of the cellular permeability that improved the utilization rate of the crude glycerol.

According to Faber et al. (2016) [52] the presence of some micronutrients present in crude glycerol could interfere in the $\mathrm{H}_{2}$ generation, increasing the amount of biogas produced. These micronutrients found in crude glycerol can be free fatty acids and sodium and potassium salts [52]. However, according to the acid pretreatment (Section 2.1) performed in the present study on crude glycerol, a large amount of free fatty acids was eliminated. As this substrate was obtained by transesterification of waste cooking oil with sodium hydroxide, the presence of sodium salts, according to Poleto et al. (2016) [53], could regulate cell osmosis. However, concentrations of this salt are required by microorganisms in different quantities, and at high concentrations, this element may inhibit cell growth. These micronutrient compositions present in the crude glycerol therefore depend on the origin of the waste cooking oils (WCO), and because it is a residue derived from a mixture of WCO, the crude glycerol of the present study comprises in a complex substrate.

\section{Contaminants of crude glycerol in kinetics of hydrogen production}

The COD values during the operation of the anaerobic batch reactors did not change significantly (COD initial $49.79 \mathrm{~g}$ COD $\mathrm{L}^{-1}$ and COD final $48.46 \mathrm{~g} \mathrm{COD} \mathrm{L}^{-1}$ for the mixed culture and $46.61 \mathrm{~g} \mathrm{COD} \mathrm{L}^{-1}$ initial and $42.58 \mathrm{~g} \mathrm{COD} \mathrm{L}^{-1}$ final for the pure culture). This fact can be explained by the glycerol metabolic pathway known for the fermentative $\mathrm{H}_{2}$-producing bacteria, suggesting that occur a transformation of the initial substrate into other volatile organic compounds, which remain in the liquid phase, causing the maintenance of COD throughout the assays [7].

The higher concentrations of secondary metabolites were ethanol (813.0 $\left.\mathrm{mg} \mathrm{L}^{-1}\right)$ for assay I and acetic acid $\left(646.0 \mathrm{mg} \mathrm{L}^{-1}\right)$ for assay II. In the glycerol pathways, $\mathrm{H}_{2}$ can be produced during oxidative metabolism (Equations (2) and (3)) [7].

$$
\begin{aligned}
& \mathrm{C}_{3} \mathrm{H}_{8} \mathrm{O}_{3} \rightarrow \mathrm{C}_{2} \mathrm{H}_{6} \mathrm{O} \text { (ethanol) }+\mathrm{CO}_{2}+\mathrm{H}_{2} \\
& \mathrm{C}_{3} \mathrm{H}_{8} \mathrm{O}_{3}+\mathrm{H}_{2} \mathrm{O} \rightarrow \mathrm{CH}_{3} \mathrm{COOH} \text { (acetic acid) }+\mathrm{CO}_{2}+3 \mathrm{H}_{2}
\end{aligned}
$$

In addition, higher yields of $\mathrm{H}_{2}$ are possible when acetic acid is generated in higher concentration during the crude glycerol fermentation, followed by ethanol. In the assay II, it was observed higher concentration of acetic acid (646.0 $\mathrm{mg} \mathrm{L}^{-1}$ ). However, would be expected that, according to the stoichiometry of glycerol fermentation by oxidative route

\begin{tabular}{|c|c|c|}
\hline Studied parameters & Assay (I)- Mixed Culture & Assay (II)-Pure Culture \\
\hline Reactors operating time $(\mathrm{h})$ & 54.80 & 90.00 \\
\hline CG initial (mg glycerol $\mathrm{mL}^{-1}$ ) & 3.00 & 3.66 \\
\hline CG final (mg glycerol $\mathrm{mL}^{-1}$ ) & 1.30 & 0.44 \\
\hline CG consumption (\%) & 56.20 & 88.00 \\
\hline $\mathrm{pH}$ (experiment end) & 5.61 & 5.70 \\
\hline $\mathrm{P}\left(\mathrm{mmol} \mathrm{H} \mathrm{L}^{-1}\right)$ & 15.14 & 4.53 \\
\hline $\mathrm{Rm}\left(\mathrm{mmol} \mathrm{h}^{-1}\right)$ & 0.29 & 0.54 \\
\hline$\lambda(\mathrm{h})$ & 0.00 & 21.18 \\
\hline $\mathrm{R}^{2}$ & 0.99 & 0.99 \\
\hline \multicolumn{3}{|l|}{ max.conc. $\left(\mathrm{mg} \mathrm{L}^{-1}\right)$} \\
\hline ethanol & 813.00 (0.080 g COD ethanol $\mathrm{g}^{-1}$ COD total) & 282.00 (0.030 g COD ethanol g ${ }^{-1}$ COD total) \\
\hline acetic acid & 551.00 (0.030 g COD acetic acid g ${ }^{-1}$ COD total) & 646.00 (0.034 g COD acetic acid g ${ }^{-1}$ COD total) \\
\hline butyric acid & 421.00 ( $0.040 \mathrm{~g}$ COD butyric acid $\mathrm{g}^{-1} \mathrm{COD}$ total) & $136.00\left(0.012 \mathrm{~g}\right.$ COD butyric acid $\mathrm{g}^{-1}$ COD total $)$ \\
\hline 1,3-PD & 0.00 & 1460.00 (0.12 g COD 1,3-PD g ${ }^{-1}$ COD total) \\
\hline methanol & 1476.00 & 1206.00 \\
\hline Hydrogen yield ( $\mathrm{mol} \mathrm{H}_{2} \mathrm{~mol}^{-1}$ glycerol) & 0.80 & 0.13 \\
\hline
\end{tabular}

\section{Table 2 - Results of the anaerobic batch reactors for the assays I and II with crude glycerol at $37^{\circ} \mathrm{C}$.}


(Equation (3)), more hydrogen would be produced. So, even for this assay, a lower generation of $\mathrm{H}_{2}$ was obtained ( $4.53 \mathrm{mmoL}$ $\mathrm{H}_{2} \mathrm{~L}^{-1}$ ) than the one of assay I with mixed culture (15.14 mmoL $\mathrm{H}_{2} \mathrm{~L}^{-1}$ ) (Fig. 3). This can be explained by the fact that the impurities present in the crude glycerol, such as methanol and soap, caused a strong negative effect on the hydrogen production with pure culture E. aerogenes [51].

In the work of Sarma et al. (2013) [51], it was investigated the effect of impurities present in crude glycerol, such as soap and methanol, during hydrogen generation and substrate consumption involving the pure culture Enterobacter aerogenes NRRL B-407. It was observed that the cumulative $\mathrm{H}_{2}$ generation decreased with the increase of crude glycerol concentration and methanol. According to Sarma et al. (2013), methanol was responsible for lower hydrogen yields. The yields for the assays executed by Sarma et al. did not exceed $2.0 \mathrm{mmoL} \mathrm{H}_{2} \mathrm{~L}^{-1}$. Methanol could be toxic to bacterial cell either by destroying their cell wall or by altering the functions of intracellular proteins.

The assay II with Enterobacter sp. was very sensitive to the presence of contaminants in the crude glycerol (methanol), thus interfering in the $\mathrm{H}_{2}$ generation, obtaining lower concentrations of this biogas than the assay I with the mixed culture.

Reungsang et al. (2013) [54] worked with a crude glycerol from a biodiesel production plant from waste cooking oil for the hydrogen generation using Enterobacter aerogenes. It was used statistical tools in the work of Reungsang et al. in order to optimize the culture conditions for the maximum hydrogen generation. Thus, it was found the following condition: $1.0 \mathrm{~g} \mathrm{~L}^{-1}$ of yeast extract, $37 \mathrm{~g} \mathrm{~L}^{-1}$ of crude glycerol, initial $\mathrm{pH}$ of 8.14 and temperature of $37^{\circ} \mathrm{C}$, obtaining a maximum generation of $0.24 \mathrm{mmoL} \mathrm{H}_{2} \mathrm{~L}^{-1} \mathrm{~h}^{-1}$. The Assay II with Enterobacter sp., a value of $0.54 \mathrm{mmoL} \mathrm{H}_{2} \mathrm{~L}^{-1} \mathrm{~h}^{-1}$ was found for the maximum rate of $\mathrm{H}_{2}$ production. This value was higher than that reported by the study of Reungsang et al. (2013) (0.24 mmoL $\left.\mathrm{H}_{2} \mathrm{~L}^{-1} \mathrm{~h}^{-1}\right)$, where the authors, even with a higher concentration of crude glycerol $\left(37.0 \mathrm{~g} \mathrm{~L}^{-1}\right)$, they obtained a lower hydrogen generation. The present study, with lower concentration of crude glycerol $\left(3.66 \mathrm{~g} \mathrm{~L}^{-1}\right)$, was capable to

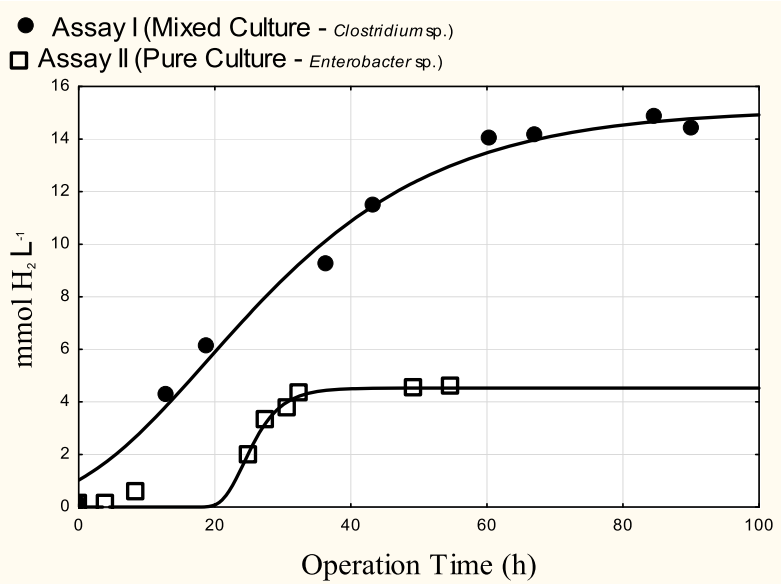

Fig. 3 - Hydrogen production by mixed (assay I) and pure culture (assay II) using the modified Gompertz function. obtain a higher rate of hydrogen generation, since less impurities were found at reduced concentrations of crude glycerol.

Ito et al. (2005) [50] compared the $\mathrm{H}_{2}$ and ethanol production from crude glycerol (by manufacturing process for biodiesel fuel) and pure glycerol with the use of Enterobacter aerogenes HU-101. For the assay with the crude glycerol, diluted with a synthetic medium containing yeast extract and tryptone, it was found the less $\mathrm{H}_{2}$ production $\left(0.70 \mathrm{moL} \mathrm{H}_{2}\right.$ $\mathrm{mol}^{-1}$ glycerol) than the assay with pure glycerol $\left(0.89 \mathrm{moL} \mathrm{H}_{2}\right.$ $\mathrm{mol}^{-1}$ glycerol). Thus, it was concluded by the authors that the $\mathrm{H}_{2}$ generation decreased with an increased in the concentrations of crude glycerol due to the presence of methanol.

Selembo et al. (2009) [55], as well as Ito et al., observed the toxic effect of methanol on Enterobacter sp. The authors evaluated the $\mathrm{H}_{2}$ production in a single-chamber mediator MEC (microbial electrolysis cells) with pure and crude glycerol (from the transesterification of soybean oil with methanol), in order to obtain higher hydrogen yields. The less yield for hydrogen production was found with crude glycerol $(1.8 \mathrm{moL}$ $\mathrm{H}_{2} \mathrm{~mol}^{-1}$ glycerol) compared with the pure glycerol $(3.9 \mathrm{moL}$ $\mathrm{H}_{2} \mathrm{~mol}^{-1}$ glycerol). According to Selembo et al., this less production was probably due to the presence of methanol in the crude glycerol.

For the biohydrogen production, the pure culture Enterobacter sp. was more sensitive than mixed culture to the presence of contaminants in the crude glycerol, such as methanol. In the literature, this specie of microorganism shown the lower potential for biogas generation compared to Clostridium sp [10].

The metabolism of Enterobacter species can produce maximum of $1 \mathrm{~mol}$ of $\mathrm{H}_{2}$ per mole of glycerol, while the metabolism of Clostridium species can produce 3 moLs $\mathrm{H}_{2}$ per mole of glycerol [10]. In the present study, the $\mathrm{H}_{2}$ yields (mol $\mathrm{H}_{2} \mathrm{~mol}^{-1}$ glycerol) were 0.83 and 0.13 , and the maximum $\mathrm{H}_{2}$ generations ( $\mathrm{mmol} \mathrm{L}^{-1}$ ) were 15.14 and 4.53 , respectively for assays I and II (Fig. 3). These results confirmed the best efficiency of mixed cultures identified as Clostridiales order (Fig. 2) for the hydrogen generation.

Metabolic pathway - oxidative and reductive

In the present study with Enterobacter sp. (assay II), it was observed that this microorganism preferred the reductive pathway, considering a generation of 1,3-PD $\left(1.46 \mathrm{~g} \mathrm{~L}^{-1}\right)$, unlike the assay I containing mixed culture that did not present 1,3PD production.

In the assay II, it was observed the acetic acid production (646.00 $\mathrm{mg} \mathrm{L}^{-1}$ ), being this one in a higher concentration than the other volatile organic compounds generated, such as ethanol (282.00 $\left.\mathrm{mg} \mathrm{L}^{-1}\right)$ and butyric acid $\left(136.00 \mathrm{mg} \mathrm{L}^{-1}\right)$. This high concentration of acetic acid may also be indicative of the metabolic pathway chosen by the Enterobacter sp. According to the equation (4), the bioconversion of the crude glycerol by the reductive pathway can generate 1,3 PD and acetic acid [56].

$2 \mathrm{C}_{3} \mathrm{H}_{8} \mathrm{O}_{3} \rightarrow \mathrm{CH}_{3} \mathrm{COOH}\left(\right.$ acetic acid) $+\mathrm{C}_{3} \mathrm{H}_{8} \mathrm{O}_{2}(1,3 \mathrm{PD})+\mathrm{CO}_{2}+2 \mathrm{H}_{2}$

Sittijunda et al. (2017) [46] related that Clostridium sp. could degrade glycerol via oxidative pathway and Enterobacter sp., as 
Table 3 - Comparative study of the bioconversion of crude glycerol to $\mathrm{H}_{2}$.

\begin{tabular}{|c|c|c|c|c|c|c|c|}
\hline \multirow[t]{2}{*}{ Substrate } & \multirow[t]{2}{*}{ Inoculum } & \multirow[t]{2}{*}{ Glycerol } & \multicolumn{3}{|c|}{$\begin{array}{l}\text { Experimental } \\
\text { conditions }\end{array}$} & \multirow{2}{*}{$\begin{array}{l}\text { Hydrogen } \\
\text { production and } \\
\text { Yield }\end{array}$} & \multirow[t]{2}{*}{ Ref. } \\
\hline & & & $\begin{array}{l}\text { Temp. } \\
\left({ }^{\circ} \mathrm{C}\right)\end{array}$ & $\mathrm{pH}$ & $\begin{array}{l}\text { Operation } \\
\text { Mode }\end{array}$ & & \\
\hline $\begin{array}{l}\text { Crude glycerol from biodiesel } \\
\text { production from restaurant } \\
\text { and meat processing industry } \\
\text { containing cooking oil and } \\
\text { animal fats }\end{array}$ & Clostridium butyricum & $17.5 \mathrm{~g} \mathrm{~L}^{-1}$ & 36 & 6.5 & Batch & $15.43 \mathrm{mmoL} \mathrm{H}_{2} \mathrm{~L}^{-1}$ & [14] \\
\hline $\begin{array}{l}\text { Crude glycerol from biodiesel } \\
\text { fuel from vegetable oil }\end{array}$ & $\begin{array}{l}\text { Mixed culture from organic soil } \\
\text { collected from an organic farm }\end{array}$ & $7,0 \mathrm{~g} \mathrm{~L}^{-1}$ & 30 & 5,5 & Batch & $\begin{array}{l}0,75 \mathrm{moL} \mathrm{H}_{2} \mathrm{~mol}^{-1} \\
\text { glicerol }\end{array}$ & [57] \\
\hline $\begin{array}{l}\text { Crude glycerol from biodiesel } \\
\text { production }\end{array}$ & $\begin{array}{l}\text { Mixed culture from an } \\
\text { anaerobic digested sludge } \\
\text { obtained from municipal } \\
\text { wastes }\end{array}$ & $10 \mathrm{~g} \mathrm{~L}^{-1}$ & 37 & 6,0 & Batch & $\begin{array}{l}0,41 \mathrm{moL} \mathrm{H}_{2} \mathrm{~mol}^{-1} \\
\text { glicerol }\end{array}$ & [58] \\
\hline $\begin{array}{l}\text { Crude glycerol from } \\
\text { transesterification process of } \\
\text { cooking used oil }\end{array}$ & $\begin{array}{l}\text { Granular sludge of UASB } \\
\text { reactor treating vinasse } \\
\text { characterized as Clostridium sp. }\end{array}$ & $3.0 \mathrm{~g} \mathrm{~L}^{-1}$ & 37 & 5.5 & Batch & $\begin{array}{l}15.14 \mathrm{moL} \mathrm{H}_{2} \mathrm{~mol}^{-1} \\
\text { glycerol }\left(2.20 \mathrm{moL} \mathrm{H}_{2}\right. \\
\left.\mathrm{mol}^{-1} \text { glycerol }\right)\end{array}$ & $\begin{array}{l}\text { Present } \\
\text { study }\end{array}$ \\
\hline
\end{tabular}

it was observed in the experimental data in the present study, degraded glycerol to 1,3-PD via reductive pathway.

The two routes (oxidative and reductive) can exist in the same organism at the same time. Therefore, in this condition, during anaerobic fermentation of glycerol, when $1 \mathrm{~mol}$ of 1,3PD is produced, $1 \mathrm{~mol}$ of $\mathrm{H}_{2}$ is consumed [19,55]. Thus, final yield of $\mathrm{H}_{2}$ is reduced by the consumption of $\mathrm{H}_{2}$ that is produced during the simultaneous production of 1,3-PD [19].

It can be attributed to the reduction of hydrogen produced by the pure culture Enterobacter sp., in addition to all that has already been mentioned in the previous sections, there was a tendency of this microorganism to follow the reductive pathway, probably due to the impurities present in the crude glycerol (methanol) that could be influenced to the change in the metabolic route, leading to the production of 1,3-PD.

\section{Yields}

For the assay I with mixed culture, characterized as Clostridium species, the yields obtained in the present study were, $0.80 \mathrm{moL} \mathrm{H}_{2} \mathrm{~mol}^{-1}$ glycerol (15.14 $\mathrm{mmoL} \mathrm{H}_{2} \mathrm{~L}^{-1}$ ) and, for the assay II with Enterobacter sp., $0.13 \mathrm{moL} \mathrm{H}_{2} \mathrm{~mol}^{-1}$ glycerol (4.53 $\mathrm{mmoL} \mathrm{H}_{2} \mathrm{~L}^{-1}$ ) (Table 2).

Pachapur et al. (2016) [14] studied the hydrogen production for bioconversion of crude glycerol using co-culture of Enterobacter aerogenes and Clostridium butyricum with Tween 80 , a non-ionic surfactant. According to them, this surfactant decreased the crude glycerol viscosity, increasing glycerol utilization along hydrogen production. With the optimized conditions of crude glycerol $\left(17.5 \mathrm{~g} \mathrm{~L}^{-1}\right)$ and Tween 80 (15 $\left.\mathrm{mg} \mathrm{L}^{-1}\right)$, the hydrogen increased, reaching $32.1 \mathrm{mmol} \mathrm{L}^{-1}$ with $87.7 \%$ of glycerol utilization. Assays with mono-culture system were done by these authors $\left(15.43 \mathrm{mmoL} \mathrm{H}_{2} \mathrm{~L}^{-1}\right.$ for Clostridium butyricum and $22.14 \pm 0.94 \mathrm{mmoL} \mathrm{H}_{2} \mathrm{~L}^{-1}$ for Enterobacter aerogenes), resulting in decreased hydrogen production compared with a co-culture system. The higher hydrogen production was possible due to the use of coculture, that increased hydrogen generation in comparison to the monoculture system and the use of Tween 80. The result for assay with Clostridium butyricum as mono culture
(15.43 $\mathrm{mmoL} \mathrm{H}_{2} \mathrm{~L}^{-1}$ ) was close to the use of mixed culture in the present study $\left(15.14 \mathrm{mmoL} \mathrm{H}_{2} \mathrm{~L}^{-1}\right)$. Thus, the use of mixed culture in the present study showed the efficient results when compared with pure culture of Clostridium sp., proving that it was possible to achieve good result using mixed cultures even with lower crude glycerol concentration $\left(3 \mathrm{~g} \mathrm{~L}^{-1}\right)$ (Table 3).

Liu et al. (2013) [57] studied the crude glycerol bioconversion, from the biodiesel production with vegetable oil, in order to generate hydrogen and 1,3-PD using as inoculum organic soil (mixed culture). The crude glycerol was separated into 4 purification steps, all of which were studied in order to obtain better yields of $\mathrm{H}_{2}$ production concomitant to the best generations of 1,3-PD, varying crude glycerol concentrations in 3, 5 and $7 \mathrm{~g} \mathrm{~L}^{-1}$. The most purified glycerol phase (when $\mathrm{KOH}$, methanol and biodiesel were removed) was the one with the best yields of $\mathrm{H}_{2}\left(0.75 \mathrm{moL} \mathrm{H}_{2} \mathrm{~mol}^{-1}\right.$ glycerol $)$ and 1,3PD (0.65 mol 1,3-propanediol $\mathrm{mol}^{-1}$ glycerol) when the glycerol concentration was $7 \mathrm{~g} \mathrm{~L}^{-1}$. This hydrogen production was lower than the present study, where even with a lower crude glycerol concentration $\left(3 \mathrm{~g} \mathrm{~L}^{-1}\right.$ ) it was possible to obtain a yield of $0.8 \mathrm{moL} \mathrm{H}_{2} \mathrm{~mol}^{-1}$ glycerol using the mixed culture as source of inoculum. Nevertheless, in the present study, a pretreatment in crude glycerol was applied in the simplest and most robust way, eliminating only a large part of the concentration of residual biodiesel present in the crude glycerol. Yet, even in this condition, it was possible to produce greater hydrogen when it was compared to the literature [57], where several pre-treatments were used in order to eliminate large amounts of contaminants, which yielded a lower yield than the present study. This showed that it was possible to reduce costs with the pretreatment of crude glycerol, as it was carried out in the present study, with only one step of pretreatment where eliminating only part of the concentration of the biodiesel residue could generate a higher $\mathrm{H}_{2}$ concentration.

Seifert et al. (2009) [58] studied the hydrogen generation from crude glycerol from the biodiesel production in fermentative processes in batch reactors. Thus, according to their study, it was possible to analyze the influence of the 
glycerol concentration, nitrogen and inoculum on the hydrogen production. It was used, in the optimized conditions, a concentration of $10.0 \mathrm{~g} \mathrm{~L}^{-1}$ of crude glycerol, generating $0.41 \mathrm{moL} \mathrm{H}_{2} \mathrm{~mol}^{-1}$ glycerol. This value was lower than the present study, when, with lower concentration of crude glycerol, it was obtained a higher hydrogen yield.

\section{Conclusion}

The Illumina MiSeq Sequencing platform allowed the characterization of the mixed culture, consisting mainly of $\mathrm{H}_{2}$ producing bacteria, such as those belonging to the Firmicutes phylum as well as those of the Clostridiales order. Thus, better results of hydrogen production with mixed culture were attributed to the predominance of Clostridiales order than the assay involving the pure culture of Enterobacter sp.

The assay containing the pure culture showed a greater utilization rate of the crude glycerol even it generating the lowest hydrogen production. This explanation is due to the facilitation of the cellular permeability given by the methanol, presented in the crude glycerol.

Enterobacter sp. was sensitive to the presence of methanol, a contaminant present in crude glycerol, which directly interfered in the metabolic pathway of hydrogen generation, resulting in lower $\mathrm{H}_{2}$ yields when compared to the assay involving mixed culture. In addition, Enterobacter sp. in the presence of crude glycerol followed the reductive pathway of bioconversion, generates $1,3-\mathrm{PD}$, which culminates in the hydrogen consumption for the generation of this compound.

The used of mixed culture can be reduced costs involved in the crude glycerol bioconversion, at the same time, is not required aseptic conditions such as pure cultures. It can be easily applied in industries to promote waste degradation and generate clean energy.

\section{Acknowledgments}

The authors gratefully acknowledge the financial support from Fundação de Amparo à Pesquisa do Estado de São Paulo (FAPESP Processes 2012/01318-01 and 2017/11767-1), CAPES and Conselho Nacional de Pesquisa e Desenvolvimento (CNPq-Proc 457144/2014-9 and 141038/2017-9) for the scholarship and CEMPEQC for support the chromatography analyses.

\section{R E F E R E N C E S}

[1] Guabiroba RCS, Silva RM, César AS, Silva MAV. Value chain analysis of waste cooking oil for biodiesel production: study case of one oil collection company in Rio de Janeiro - Brazil. J Clean Prod 2017;142:3928-37.

[2] Mansir N, Teo SH, Rashid U, Saiman MI, Tan YP, Alsultan GA, et al. Modified waste egg shell derived bifunctional catalyst for biodiesel production from high FFA waste cooking oil. A review. Renew Sustain Energy Rev 2018;82:3645-55.

[3] SABESP. Programa de Reciclagem de Óleo de Fritura da Sabesp. 2016 [Accessed 24 July 2017], http://site.sabesp.com. br/uploads/file/asabesp_doctos/programa_reciclagem_oleo_ completo.pdf.

[4] APROBIO. Brasil recicla 30 milhões de litros de óleo de cozinha na produção de biodiesel. Associação dos Produtores de Biodiesel no Brasil; 2017. p. 1-3 [Accessed 24 July 2017], http://aprobio.com.br/2017/01/10/brasil-recicla-30-milhoesde-litros-de-oleo-de-cozinha-na-producao-de-biodiesel/.

[5] ANP. Boletim mensal do biodiesel-Jan de 2017. 2017 [Accessed 24 July 2017], http://www.anp.gov.br/wwwanp/images/ publicacoes/boletins-anp/Boletim_Mensal_do_Biodiesel/ 2017/Boletim_Biodiesel_FEVEREIRO_2017.pdf.

[6] Tangy A, Pulidindi IN, Perkas N, Gedanken A. Continuous flow through a microwave oven for the large-scale production of biodiesel from waste cooking oil. Bioresour Technol 2017;224:333-41.

[7] Rodrigues CV, Santana KO, Nespeca MG, De Oliveira JE, Maintinguer SI. Crude glycerol by transesterification process from used cooking oils: characterization and potentialities on hydrogen bioproduction. Int J Hydrogen Energy 2016;41(33):14641-51.

[8] CEMPRE. Compromisso Empresarial para Reciclagem. 2017 [Accessed 24 July 2017], http://cempre.org.br/cempre-informa/ id/96/preco-do-material-reciclavel.

[9] ABIOVE. Associaçao Brasileira das Indústrias de Óleos Vegetais. Arquivos com estatísticas do biodiesel. Biodiesel: produção por tipo de matéria-prima. 2017 [Accessed 24 July 2017], http://www.abiove.org.br/site/index.php? page $=$ estatistica\&area $=$ NCOyLTE $=$.

[10] Sarma S, Dubey VK, Moholkar VS. Kinetic and thermodynamic analysis (with statistical optimization) of hydrogen production from crude glycerol using Clostridium pasteurianum. Int J Hydrogen Energy 2016;41(44):19972-89.

[11] Pachapur VL, Das RK, Brar SK, Bihan YL, Buelna G. Valorization of crude glycerol and eggshell biowaste as media components for hydrogen production: a scale-up study using co-culture system. Bioresour Technol 2017;225:386-94.

[12] Hejna A, Kosmela P, Formela K, Piszczyk L, Haponiuk JT. Potential applications of crude glycerol in polymer technology- Current state and perspectives. Renew Sustain Energy Rev 2016;66:449-75.

[13] Luo X, Ge X, Cui S, Li Y. Value-added processing of crude glycerol into chemicals and polymers. Bioresour Technol 2016;215:144-54.

[14] Pachapur VL, Sarma SJ, Brar SK, Bihan YL, Buelna G, Verma M. Surfactant mediated enhanced glycerol uptake and hydrogen production from biodiesel waste using coculture of Enterobacter aerogenes and Clostridium butyricum. Renew Energy 2016;95:542-51.

[15] Maru BT, López F, Kengen SWM, Constantí M, Medina F. Dark fermentative hydrogen and ethanol production from biodiesel waste glycerol using a co-culture of Escherichia coli and Enterobacter sp. Fuel 2016;186:375-84.

[16] Cofré O, Ramírez M, Gómez JM, Cantero D. Pilot scale fedbatch fermentation in a closed loop mixed reactor for the biotransformation of crude glycerol into ethanol and hydrogen by Escherichia coli MG 1655. Biomass Bioenergy 2016;91:37-47.

[17] Pachapur VL, Sarma SJ, Brar SK, Bihan YL, Buelna G, Soccol CR. Evidence of metabolic shift on hydrogen, ethanol and 1,3-propanediol production from crude glycerol by nitrogen sparging under micro-aerobic conditions using coculture of Enterobacter aerogenes and Clostridium butyricum. Int J Hydrogen Energy 2015;40:8669-76.

[18] Drożdżyńska A, Leja K, Czaczyk K. Biotechnological production of 1,3-propanediol from crude glycerol. J Biotechnol Computational Biol and Bionanotechnol 2011;92(1):92-100. 
[19] Sarma SJ, Brar SK, Sydney EB, Bihan YL, Buelna G, Soccol CR. Microbial hydrogen production by bioconversion of crude glycerol: a review. Int J Hydrogen Energy 2012;37(8):6473-90.

[20] Kurahashi K, Kimura C, Fujimoto Y, Tokumoto H. Valueadding conversion and volume reduction of sewage sludge by anaerobic co-digestion with crude glycerol. Bioresour Technol 2017;232:119-25.

[21] Rai PK, Singh SP. Integrated dark-and photo-fermentantion: recent advances and provisions for improvement. Int J Hydrogen Energy 2016;41(44):19957-71.

[22] Chookaew T, O-Thong S, Prasertsan P. Statistical optimization of medium components affecting simultaneous fermentative hydrogen and ethanol production from crude glycerol by thermotolerant Klebsiella sp. TR17. Int J Hydrogen Energy 2014;39(2):751-60.

[23] Chookaew T, O-Thong S, Prasertsan P. Fermentative production of hydrogen and soluble metabolites from crude glycerol of biodiesel plant by the newly isolated thermotolerant Klebsiella pneumoniae TR17. Int J Hydrogen Energy 2012;37(18):13314-22.

[24] Trchounian K, Müller N, Schink B, Trchounian A. Glycerol and mixture of carbon sources conversion to hydrogen by Clostridium beijerinckii DSM791 and effects of various heavy metals on hydrogenase activity. Int J Hydrogen Energy 2017;42(12):7875-82.

[25] Chi Z, Pyle D, Wen Z, Frear C, Chen S. A laboratory study of producing docosahexaenoic acid from biodiesel-waste glycerol by microalgal fermentation. Process Biochem 2007; 42(11):1537-45.

[26] Ethier S, Woisard K, Vaughan D, Wen Z. Continuous culture of the microalgae Schizochytrium limacinum on biodieselderived crude glycerol for producing docosahexaenoic acid. Bioresour Technol 2011;102(1):88-93.

[27] Maintinguer SI, Fernandes BS, Duarte ICS, Saavedra NK, Adorno MAT, Varesche MB. Fermentative hydrogen production by microbial consortium. Int J Hydrogen Energy 2008;33(16):4309-17.

[28] Griffiths RI, Whiteley AS, O'donnell AG, Bailey MJ. Rapid method for coextraction of DNA and RNA from natural environments for analysis of ribosomal DNA- and rRNAbased microbial community composition. Appl Environ Microbiol 2000;66(12):5488-91.

[29] Cole JR, Wang Q, Fish JA, Chai B, McGarrell DM, Sun Y, et al. Ribosomal database project: data and tools for high throughput rRNA analysis. Nucleic Acids Res 2014;42:D633-42.

[30] Caporaso JG, Kuczynski J, Stombaugh J, Bittinger K, Bushman FD, Costello EK, et al. QIIME allows analysis of high-throughput community sequencing data. Br J Pharmacol 2010;7:335-6.

[31] Maintinguer SI, Lazaro CZ, Pachiega R, Varesche MBA, Sequinel R, Oliveira JE. Hydrogen bioproduction with Enterobacter sp. isolated from brewery wastewater. Int J Hydrogen Energy 2017;42(1):152-60.

[32] Dhole V, Kadam V. Advantages of the TOGA-Transformer Oil Gas Analyzer involving headspace-GC analysis and a DGA system. Application note 10348. Nasik, India: Thermo Fisher Scientific; 2012.

[33] Sequinel R. Caracterização físico-química da glicerina proveniente de usinas de bio- diesel e determinação de metanol residual por CG com amostragem por Headspace estático. PhD Thesis. UNESP-Instituto de Química de Araraquara; 2013.

[34] Adorno MAT, Hirasawa JS, Varesche MBA. Development and validation of two methods to quantify volatile acids (C2-C6) by GC/FID: headspace (Automatic and Manual) and LiquidLiquid Extraction (LLE). Am J Anal Chem 2014;5:406-14.
[35] Bondioli P, Bella DL. An alternative spectrophotometric method for the determination of free glycerol biodiesel. Eur J Lipid Sci Technol 2005;107(3):153-7.

[36] APHA AWWA WEF. In: Standard methods for the examination of water and wastewater: American Public Health Association. 21th ed. American Water Works Association, Water Environment Federation; 2005 [Centennial Edition].

[37] Lay J-J, Li Y-Y, Noike T. Developments of bacterial population and methanogenic activity in a laboratory-scale landfill bioreactor. Water Res 1998;32(12):3673-9.

[38] Xie X, Liu N, Yang B, Yu C, Zhang Q, Zheng X, et al. Comparison of microbial community in hydrolysis acidification reactor depending on different structure dyes by Illumina MiSeq sequencing. Int Biodeterior Biodegrad 2016;111:14-21.

[39] Ratti RP, Delforno TP, Okada DY, Varesche MBA. Bacterial communities in thermophilic $\mathrm{H}_{2}$-producing reactors investigated using 16S rRNA 454 pyrosequencing. Microbiol Res 2015;173:10-7.

[40] Torquato LDM, Pachiega R, Crespi MS, Nespeca MG, Oliveira JE, Maintinguer SI. Potential of biohydrogen production from effluents of citrus processing industry using anaerobic bacteria from sewage sludge. Waste Manag 2017;59:181-93.

[41] Guwy AJ, Dinsdale RM, Kim JR, Massanet-Nicolau J, Premier G. Fermentative biohydrogen production systems integration. Bioresour Technol 2011;102:8534-42.

[42] Martin PCB, Schlienz M, Greger M. Production of biohydrogen and methane during semi-continuous digestion of maize silage in a two-stage system. Int J Hydrogen Energy 2017;42:5768-79.

[43] Rosa PRF, Santos SC, Sakamoto IK, Varesche MBA, Silva EL. Hydrogen production from cheese whey with ethanol-type fermentation: effect of hydraulic retention time on the microbial community composition. Bioresour Technol 2014;161:10-9.

[44] Maintinguer SI, Sakamoto IK, Adorno MAT, Varesche MBA. Bacterial diversity from environmental sample applied to bio-hydrogen production. Int J Hydrogen Energy 2015;40:3180-90.

[45] Wirth R, Kovács E, Maróti G, Bagi Z, Rákhely G, Kovács KL. Characterization of a biogas-producing microbial community by short-read next generation DNA sequencing. Biotechnol Biofuels 2012;5(41):1-16.

[46] Sittijunda S, Reungsang A. Fermentation of hydrogen, 1,3propanediol and ethanol from glycerol as affected by organic loading rate using up-flow anaerobic sludge blanket (UASB) reactor. Int J Hydrogen Energy 2017;42(45):27558-69.

[47] Rainey FA. Class II. Clostridia class. nov. In: De Vos P, Garrity GM, Jones D, Krieg NR, Ludwig W, Rainey FA, et al., editors. Bergey's mannual of systematic bacteriology. Second ed.3. New York: Springer; 2009. p. 736.

[48] Amann RI, Ludwig W, Schleifer KH. Phylogenetic identification and in situ detection of individual microbial cells without cultivation. Microbiol Rev 1995;59:143-69.

[49] Maintinguer SI, Fernandes BS, Duarte ICS, Saavedra NK, Adorno MAT, Varesche MB. Fermentative hydrogen production with xylose by Clostridium and Klebsiella species in anaerobic batch reactors. Int J Hydrogen Energy 2011;36(21):13508-17.

[50] Ito T, Nakashimada Y, Senba K, Matsui T, Nishio N. Hydrogen and ethanol production from glycerol-containing wastes discharged after biodiesel manufacturing process. J Biosci Bioeng 2005;100(30):260-5.

[51] Sarma Sj, Dhillon Gs, Brar Sk, Bihan Yl, Buelna G, Verma M. Investigation of the effect of different crude glycerol 
components on hydrogen production by Enterobacter aerogenes NRRL B-407. Renew Energy 2013;60:566-71.

[52] Faber MO, Ferreira-Leitão VS. Optimization of biohydrogen yield produced by bacterial consortia using residual glycerin from biodiesel production. Bioresource Techonol 2016;219:365-70.

[53] Poleto L, Souza P, Magrini FE, Beal LL, Torres ANR, Sousa MP, et al. Selection and identification of microorganisms present in the treatment of wastewater and actived sludge to produce biohydrogen from glycerol. Int J Hydrogen Energy 2016;41(7):4374-81.

[54] Reungsang A, Sittijunda S, Angelidaki I. Simultaneous production of hydrogen and ethanol from waste glycerol by Enterobacter aerogenes KKU-S1. Int J Hydrogen Energy 2013;38:1813-25.

[55] Selembo PA, Perez JM, Lloyd WA, Logan BE. High hydrogen production from glycerol or glucose by electrohydrogenesis using microbial electrolysis cells. Int J Hydrogen Energy 2009;34(13):5373-81.

[56] Maintinguer Sandra Imaculada, Hatanaka Rafael Rodrigues, de Oliveira José Eduardo. Glycerol as a raw material for hydrogen production. In: Biernat Krzysztof, editor. Biofuels status and perspective. InTech; 2015. https://doi.org/10.5772/ 60013 [Accessed 9 October 2015] Available from: https://www. intechopen.com/books/biofuels-status-and-perspective/ glycerol-as-a-raw-material-for-hydrogen-production.

[57] Liu B, Christiansen K, Parnas R, Xu Z, Li B. Optimizing the production of hydrogen and 1,3-propanediol in anaerobic fermentation of biodiesel glycerol. Int J Hydrogen Energy 2013;38(8):3196-205.

[58] Seifert K, Waligorska M, Wojtowski M, Laniecki M. Hydrogen generation from glycerol in batch fermentation process. Int $J$ Hydrogen Energy 2009;34(9):3671-8. 